This item was submitted to Loughborough's Research Repository by the author.

Items in Figshare are protected by copyright, with all rights reserved, unless otherwise indicated.

\title{
Lifeworld and systems in the digital economy
}

PLEASE CITE THE PUBLISHED VERSION

https://doi.org/10.1177/1368431017709703

PUBLISHER

(C) The Author. Published by SAGE Publications (UK and US)

VERSION

AM (Accepted Manuscript)

PUBLISHER STATEMENT

This work is made available according to the conditions of the Creative Commons Attribution-NonCommercialNoDerivatives 4.0 International (CC BY-NC-ND 4.0) licence. Full details of this licence are available at: https://creativecommons.org/licenses/by-nc-nd/4.0/

\section{LICENCE}

CC BY-NC-ND 4.0

\section{REPOSITORY RECORD}

Elder-Vass, Dave. 2019. "Lifeworld and Systems in the Digital Economy". figshare. https://hdl.handle.net/2134/23642. 


\section{Lifeworld and systems in the digital economy}

Dave Elder-Vass

Loughborough University, Loughborough, UK

Corresponding author: Dave Elder-Vass, Department of Social Sciences, Loughborough University, Ashby Road, Loughborough, LE11 3TU, United Kingdom

Email: d.elder-vass@lboro.ac.uk

\section{Abstract}

The digital economy has provided opportunities for new forms of economic practice. At their purest, these forms deliver economic benefits as gifts and depend on cooperation without authority. Drawing loosely on Habermas, we may call this a lifeworld economy - an economy that is coordinated by communicative interaction - as opposed to the systems economy of market and state, coordinated by money and power.

This formulation, however, faces both theoretical and practical challenges. On the theoretical side, the notion of a lifeworld economy does not sit easily with Habermas's own formulation of the distinction between lifeworld and systems. On the practical side, the digital lifeworld economy has been colonised steadily by capitalist businesses, which have frequently found ways to incorporate forms of gift and cooperation into profit-oriented business models.

This paper proposes to reformulate Habermas's distinction as a reference to different kinds of causal mechanisms, detaching it from his functionalist framework and enabling more flexible application to empirical cases. It then applies it to a series of iconic cases from the digital economy: amazon, Wikipedia, and open source software, to demonstrate its continuing relevance to very current issues.

Keywords: amazon, digital economy, Habermas, lifeworld, open source, Wikipedia 
Jürgen Habermas has famously bemoaned the colonisation of the lifeworld by the logic of systems, most strikingly through the spread of market exchange into more and more areas of social life (Habermas, 1987). His distinction between lifeworld and systems, however, has attracted significant criticism, and it is far from clear how it applies to empirical cases. This paper investigates an alternative perspective by offering a different way to think about the distinction and applying it to some iconic cases from the contemporary digital economy.

The digital economy has provided opportunities for new forms of economic practice, forms that entail a very different kind of moral economy than market capitalism. At their purest, these forms deliver economic benefits as gifts and depend on cooperation without authority. Drawing loosely on Habermas's terminology, this appears to be a lifeworld economy - an economy that is coordinated by communicative interaction - as opposed to the systems economy of market and state, coordinated by money and power. However, the digital lifeworld economy has been colonised steadily by capitalist businesses, which have frequently found ways to incorporate forms of gift and cooperation into profit-oriented business models.

The paper begins by discussing the concept of the economy, arguing that the many varied economic forms to be found in the digital economy reinforce an important argument: that we need to think of the economy more flexibly than is usually the case, to include all kinds of provisioning and not just those that operate through the market (thus acknowledging the possibility that there might be lifeworld forms of economy). It then discusses Habermas's concepts of lifeworld and system, noting some of the criticisms that have been made of them and suggesting an alternative way of framing them. Then we turn to a group of empirical cases that are used to develop the argument - amazon, Wikipedia and open source software. Finally, the concluding sections examine the implications for the viability and critical value of Habermas's distinction.

\section{Diversity in the economy}

The very idea that there could be lifeworld forms within the economy may seem odd, as Habermas generally represents the economy as part of the realm of systems rather than the lifeworld. This, however, rests on implicitly identifying the economy with the market, and in doing so Habermas is, ironically, following one of the dominant discursive trends of our times: the reduction of economic activity to the production and sale of commodities. For anyone interested in the possibility of alternative ways of running the economy, this discursive trend must be 
rejected and resisted (Gibson-Graham, 2006a, 2006b). If we accept that the economy is by definition a realm of commodities, then we have already given up the possibility of non-market forms of the economy. Yet both history and anthropology tell us that the function of the economy can be performed by non-market forms, such as feudalism, for example, and the gift economy described by Mauss (2002).

It makes more sense, then, to define the economy in terms of its function, and there is already a significant tradition that does so, using the concept of provisioning (e.g. Boulding, 1973; ElderVass, 2016: chapter 2; Garnett, 2007; Gruchy, 1987; Nelson, 1993; Power, 2004; Sayer, 2004). ${ }^{1}$ Provisioning refers to the activities that human beings undertake to provide for the needs of human beings (Nelson, 1993: 32-4) and therefore includes not only the activities that are undertaken in the market economy, but also a vast range of other activities that are generally ignored and excluded by conventional understandings of the economy. Most strikingly, it includes those that provide goods for people who cannot afford to buy what they need on the market, and those that fulfil our collective need for public goods. Thus, for example "growing some carrots would count as provisioning and thus as economic whether I did it in my back garden for consumption by my family or whether a farmer did it for sale to a supermarket who then sold the carrots on to me" (Elder-Vass, 2016: 29).

Once we begin to see the economy as a provisioning economy, we also start to see something that the prevailing discursive regime renders invisible: that there are already huge non-market sectors of our existing economy (Elder-Vass, 2016: chapter 2; Hart et al., 2010: 5). GibsonGraham $^{2}$, for example, argue that if we can see our way past the prevailing discursive regime "we could begin to see a huge state sector... a very large sector of self-employed and family-based producers (most noncapitalist), [and] a huge household sector" (Gibson-Graham, 2006b: 263). On one estimate, in a typical relatively wealthy contemporary country the work performed in the household sector alone is as large as the market sector (Ironmonger, 1996), and in less developed economies family agricultural production can also be similar in scale to the market sector. The product of work in these sectors is often transferred in the form of gifts, in the sense that no direct and immediate return is expected. Perhaps most typically these are gifts to family members, but there are also significant transfers to strangers, notably through charity, volunteering and the digital economy (Elder-Vass, 2015a). The gift economy, it turns out, is not a marginal survival from pre-modern times but a continuing and vibrant element of contemporary societies (Elder-Vass, 2016: 32-5). 
One consequence is that conventional academic ways of analysing the economy are thoroughly inadequate. Both mainstream economics and many of the more heterodox traditions begin from the assumption that the economy can be identified with the market and production for the market, and build accounts of the economy that are so deeply ingrained with this assumption that they are utterly meaningless outside the context of the market economy. ${ }^{3}$ If we are to make sense of a more diverse economy, we will need different frameworks that can accommodate both market and non-market economic forms. Elsewhere I have argued that we should think of the economy as a variety of competing and interacting economic forms, each of which can be characterised as a complex of practices (Elder-Vass, 2016: chapter 5). We can then examine each distinctive complex of practices and start to theorise how it works, what effects it tends to have, and how it interacts with other forms in the economic environment. As we shall see, the digital economy is the site of a broad range of interesting and innovative forms, with market, nonmarket and hybrid forms interacting diversely.

\section{Lifeworld and systems}

The tension between the market and non-market sectors of the provisioning economy invites comparison with Habermas's analysis of the distinction between lifeworld and systems. Habermas begins from a distinction between instrumental strategic action ("action oriented to success") and communicative action ("action oriented to mutual understanding") (Habermas, 1987: 180), then distinguishes

mechanisms for coordinating action that harmonize the action orientations of participants from mechanisms that stabilize nonintended interconnections of actions by way of functionally intermeshing action consequences. In one case, the integration of an action system is established by a normatively secured or communicatively achieved consensus, in the other case, by a nonnormative regulation of individual decisions that extends beyond the actors' consciousnesses. This distinction between a social integration of society, which takes effect in action orientations, and a systemic integration, which reaches through and beyond action orientations, calls for a corresponding differentiation in the concept of society itself. No matter whether one starts with Mead from basic concepts of social interaction or with Durkheim from basic concepts of collective representation, in either case society is conceived from the perspective of acting subjects as the lifeworld of a social group. In contrast, from the observer's perspective of someone not involved, society can be conceived only as a system of actions such that 
each action has a functional significance according to its contribution to the maintenance of the system. (Habermas, 1987: 117)

Here Habermas is aligning, and arguably conflating, a bewildering array of different distinctions, between: (i) different kinds of action; (ii) different mechanisms for coordinating action, which may or may not be the same thing as (iii) different means of integrating an action system - social integration and systemic integration; and which is reflected in (iv) two different concepts of society, which correspond to the actor's perspective of society as "the lifeworld of a social group", and the observer's perspective of society as a functional system. This must leave us wondering whether these two different concepts of society correspond to $(v)$ two different substantive phenomena (or types of phenomena) and Habermas goes on to confirm that this is indeed the case: the social "is split up into spheres of action constituted as the lifeworld and spheres neutralized against the lifeworld. The former are communicatively structured, the latter formally organized" (Habermas, 1987: 309).

The core of the argument seems to be that the lifeworld is those areas or aspects of the social world where action is co-ordinated by communicative interaction ("socially integrated"), whereas systems are those areas or aspects where action is co-ordinated by the steering media of money and power ("systemically integrated"). Systemic integration operates not through the actors concerned reaching agreement but through processes "over which [the actors] have neither full control nor full consciousness in their everyday life" (Chernilo, 2002: 439). Habermas also argues that lifeworld and systems can be aligned with different functional aspects of society: "In bourgeois society, over against those areas of action that are systemically integrated in the economy and the state, socially integrated areas of action take the shape of private and public spheres" (Habermas, 1987: 318). In a clear echo of Parsons' AGIL schema, systems appear to rule the economy (A) and the state (G), while the lifeworld is the realm of norms and values (IL) (Chernilo, 2002: 441; Mouzelis, 1997: 115).

Habermas connects this argument to a critical agenda. ${ }^{4}$ Criticising Weber and (by implication) his predecessors in the Frankfurt School for seeing modern reason as purely instrumental (Rasmussen, 1990: 26-8), he argues that there is a second, more fundamental and more ethical form of modern rationality: communicative rationality, in which we "think together in shared intersubjective contexts" (Plumb, 2014: 49). In the modern world, however, systems have progressively colonised the lifeworld - instrumental rationality has eclipsed communicative rationality. This has taken place in the economy, which is increasingly ruled by monetary 
exchange and the capitalist logic of markets (commodification), and in the state, which increasingly governs through impersonal rules and law (juridification). In juridification, legal authority takes over functions previously managed within the lifeworld, such as social workers taking away neglected and abused children from their families. In commodification, the expansionist logic of capitalism drives a market takeover of functions previously managed within the lifeworld, such as parents handing over childcare to nurseries. Habermas is not entirely opposed to this development - he recognises that systems play an essential and valuable role in contemporary society (Finlayson, 2005: 54-5). But he is concerned that it is going too far - that systems are expanding beyond those areas in which they are beneficial. For example, while they may be suitable for governing material reproduction, the intrusion of systems into the symbolic reproduction of the lifeworld cannot be achieved "without pathological side-effects" (Habermas, 1987: 333). In particular, systems depend on the normative foundations provided by the lifeworld, but if they intrude too far they are in danger of destroying those very foundations: "although the system is embedded in and depends on the lifeworld, the former tends to encroach upon, to displace and even destroy, the latter" (Finlayson, 2005: 56; also see Outhwaite, 1994: 90).

There is something attractive about Habermas's argument: both capitalist markets and impersonal rules seem to dehumanise contemporary society just at the time when we were being freed enough from repressive traditional morality to develop more human, more democratic and more inclusive ways of living together. Modernity has both the potential to increase our freedom and the potential to prevent that, and Habermas's analysis leads us to the energising political conclusion that we can and should resist the dehumanising forces of modernity by employing the communicative powers that it also releases. But is it coherent as a social theory and is it viable as social ontology?

Numerous criticisms of his argument can be found in the literature. Mouzelis, for example, argues that Habermas conflates a methodological distinction between the participant and observer perspectives with a substantive distinction between different spheres of interaction (Mouzelis, 1997: 115). Similarly, Joas has argued that Habermas tends to slide between the distinctions between "types of action, types of coordination of action, and societal domains" (Joas, 1991: 104; Outhwaite, 1994: 113), thus seeming to imply that a single type of action and a single form of coordination of action is to be found in each of the two primary domains. There are also concerns that the idea that coordination is achieved in the lifeworld through actions oriented to achieving understanding glosses over the important roles played by power and 
systems of inequality within the lifeworld. Habermas does recognise that power and strategic action operate within the lifeworld (Habermas, 1991: 258), but it is still tempting to see his message as "system bad, lifeworld good" (Outhwaite, 1994: 114). It would be more accurate to see Habermas as favouring a modern, communicatively rationalised lifeworld based on agreement reached through free discussion, while also recognising that the lifeworld includes more repressive normative structures such as patriarchal family relations and traditions of prejudice and discrimination. ${ }^{5}$ There is thus a sense in which he advocates the spread of communicative rationality within the lifeworld as well as seeing resistance to systems in these terms.

All of these criticisms can be seen as demands to unpick the five-fold conflation of different distinctions that Habermas builds into his understanding of lifeworld and systems: a fundamentally dualistic conflation in which his entire understanding of society is structured around "the conflict between instrumental and communicative rationality" (Delanty, 1999: 79). Habermas's critics have also questioned his identification of lifeworld and system with particular domains (Habermas, 1987: 322) or spheres (Habermas, 1987: 309, 317) or areas (Habermas, 1987: 318-9) of action. For example, Mouzelis argues that

labelling the A and G subsystems as the System and the I and L ones as lifeworld builds into the very definition of these two terms, and therefore solves aprioristically, the substantive, empirical issue of how important steering and non-steering mechanisms of co-ordination are in each institutional sphere. In that sense it may lead to the false impression ... that there are no economic or political lifeworlds (Mouzelis, 1997: 115-6).

Other critics have generalised the issue further. McCarthy suggests that "most, if not all, domains of social action can be looked at in both ways" (i.e. as realms of both social and systems integration) (McCarthy, 1991: 130). Fraser argues that social integration and system integration are often mixed, and the distinction cannot distinguish "the capitalist economy... from the modern nuclear family, for both of these institutions are mélanges of consensuality, normativity, and strategicality" (Fraser, 1989: 118). While Fraser's critique is focused on the gender blindness of Habermas's categories - since, for example, they direct attention away from the labour women do in the household - it also, like Mouzelis and McCarthy, strikes at the ontology of Habermas's distinction. The issue is made even clearer by Honneth, as interpreted here by Rasmussen: 
the distinction between system and lifeworld functions as a kind of dualism which enables communication to be separated from power. Ultimately, the distinction is based upon two theoretical fictions, namely, that an action system can occur independently of the normative building of consensus, and that a communicatively integrated action sphere, the lifeworld, can occur independently of domination by relations of power (Rasmussen, 1990: 51).

Neither of these fictions is tenable. Power and money clearly operate within the household, for example, and within the public sphere of social and political debate, but equally actions in the market are shaped by normative factors and agreements reached discursively. We must therefore question Habermas's claim that there are distinct domains of systems and lifeworld, if it means that these are two separate groups or types of actions occurring in two different social spheres.

Habermas himself paid less attention to the problematic of systems and lifeworld in his later work, perhaps in recognition of its weaknesses. Gray, for example, argues that in his account of law and politics in Between Facts and Norms Habermas moved towards a Luhmannite systems framework in which society is seen as a system of communications (Gray, 2014). This would seem to entail seeing both sides of Habermas's earlier binary as both systemic and communicative, though perhaps as different communicative subsystems. But Luhmann's collapsing of social systems into nothing but meaning and communication is fundamentally untenable, not least because it neglects the role of people in the production of communications (Elder-Vass, 2007), taking functionalism's focus on society at the expense of the individual to its logical and ultimately self-destructive extreme.

This paper, instead, seeks to reposition the most valuable parts of Habermas's argument into a different ontological framework, ${ }^{6}$ moving in a realist rather than a constructionist direction from his initial starting point. The proposal it considers is that the concepts of lifeworld and system can be rescued by reframing them, not as types or domains of action, but as classes of causal mechanism, and that this may be able to restore their critical usefulness. This involves (a) picking out one of Habermas's formulations of the distinction: "mechanisms for coordinating action that harmonize the action orientations of participants" versus "mechanisms that stabilize nonintended interconnections of actions by way of functionally intermeshing action consequences" (Habermas, 1987: 117); (b) splitting it away from assumptions of congruence with particular types of action or social domains; and (c) moving it out of the functionalist framework 
employed by Habermas into a realist causal framework, where mechanisms are significant not because they harmonise the social world but because they generate causal powers (Bhaskar, 1975; Elder-Vass, 2010b). ${ }^{7}$

The lifeworld, in this framework, refers to those mechanisms that arise from the communicative features of interaction, and systems refers to those mechanisms that arise from the use of steering media (money and power - if it really makes sense to group these two together). ${ }^{8}$ Now we may say, for example, that when a sergeant orders a private to clean her boots, a systems mechanism is at work, since the mechanism that enables the sergeant to do so depends on the institutionalisation of a power relation which does not require agreement to be reached by the affected parties for an order to be issued. Or when potential buyers compete to buy an item in an online auction, a systems mechanism is at work, since the mechanism that determines who wins the auction is an alienated process that requires no discussion between the parties. Or when cheap oil encourages us all to burn carbon, producing global warming and climate change, a systems mechanism is at work, since the consequences of all of our actions are aggregated in causal chains of which the participants have no awareness. Or when a person asks whether her friend would like cup of coffee, a lifeworld mechanism is at work, since the outcome depends on a process of interactive communication oriented to reaching agreement.

These cases would perhaps fit quite easily into Habermas's own version of the argument, but there are also many cases that cannot be categorised so neatly. Consider the case of parents who take their child to a commercial nursery for care during work hours. Responsible parents will want to visit the nursery and talk to the staff in order to judge the quality of care, to discuss their child's particular needs with them and how well they can be met, and will make a decision about whether or not to use the nursery based on these processes of communication oriented to reaching agreement as well as on the basis of whether they can afford the fees and consider them good value. Here both lifeworld and systems mechanisms interact to influence the outcome - and indeed other mechanisms that are perhaps neither, such as the influence of the spatial location of the nursery on their decision. There is no one sphere of action in which the parents' decision belongs, but simply different mechanisms that interact.

\section{From amazon to Wikipedia}

Let me consider how this framework could be applied to some cases from the diverse digital economy, beginning with a case that at first sight fits rather well with Habermas's view of the economy as part of the domain of systems: the online retailer amazon.com. Amazon is very much 
a part of the commodity economy, and has established a massive market share through a combination of aggressive pricing, vast range, rapid delivery and high quality product information that helps buyers choose the most suitable product for their needs (Stone, 2014). It provides an environment in which buyers can easily make instrumentally rational buying decisions, with price as a key variable, and even provides selling space for smaller competing vendors on its site, so that buyers can make choices between vendors without leaving the site (Jopson, 2012a). Its own pricing is responsive to market forces, and its third party marketplace creates a space where competition on price and other variables can operate easily. There are even cases where price movements are automated by systems that adjust a seller's prices to those offered by competing sellers (Geldman, 2014; Jopson, 2012b: 270-332). Hence the actions of buyers and sellers on the amazon website are instrumental, they are coordinated at the level of pricing movements through a systemic mechanism that operates behind the backs of the buyers themselves while depending on their actions, and they take place within the economy.

So far this seems to support Habermas's position, but we must not neglect the lifeworld elements that also affect buying decisions in this context. When we buy, we have reasons for wanting what we buy, which tend to be influenced by lifeworld mechanisms. When someone uses amazon to buy a birthday present for a friend, for example, they are likely to base their buying decision on a history of communicative interaction - they might even have asked the friend what she would like. Or a buyer may have discussed the need for a certain item with their partner, looked at the options on amazon and decided together, in the light of both price and reviews, to purchase a particular product. In these cases, communicative interaction has clearly contributed to the purchasing process.

Furthermore, the decisions we make about exactly what to buy are often influenced by the reviews written by other customers and published on the amazon web site. Amazon publishes those reviews for strategic reasons, but in doing so they provide a forum for communicative interaction - an opportunity for us to shape decisions on the basis of the views of others and an assessment of how well those views fit with our own needs. Granted, there isn't a great deal of two-way interaction here, so this isn't communication that is oriented to securing agreement between the communicators, but neither is it communication that is oriented to securing instrumental advantage for the original communicator - this is a form of communication that seems to sit somewhere in between the ideal types of strategic and communicative action offered by Habermas. 
Even on amazon, then, it is clear that the actions of purchasers are influenced by both systems and lifeworld mechanisms. What about sellers? Amazon itself, and the other sellers on its site, are arguably more strategically motivated than the typical buyer, but in the reframed version of the argument that does not necessarily entail that there has been a systems influence - it is entirely possible for strategically motivated actors to make decisions in the light of communication oriented to securing agreement. The systems influence here arises, rather, from other mechanisms, and most clearly from the mechanism of the market: sellers must respond to the pricing strategies of other players in the market because if they cease to be competitive they will lose sales. Thus, for example, the management team of an amazon marketplace seller may go through a communicative process oriented to securing agreement, though no doubt influenced by differentials in power, to determine their pricing strategy. Whether that pricing strategy succeeds or fails, however, and thus whether it is sustainable, will depend on the systemic forces of the market. Thus, like buyers, the actions of sellers may be influenced by both systems and lifeworld forces. We may consider that the balance of their influence differs between the typical buyer and the typical seller, but we cannot conclude that amazon is purely in one domain or the other.

If amazon looks at first sight like a classic case of systems logic at work, Wikipedia may seem like the archetype of a lifeworld ecosystem. It provides a product - online encyclopaedia articles that is given away for nothing to anyone that chooses to use it. The creators of that product Wikipedia's editors - work on it for no monetary reward and choose their own tasks (Benkler, 2002: 375-6; Elder-Vass, 2016: 154-8). The running costs of the site are met entirely by voluntary donations. Hence the systems logic of the market has no direct influence on the day to day operation of the site. Furthermore, decisions and disputes about the content of the site are conducted through open debate on Wikipedia's talk pages, in an environment where the offline identities of the participants are mostly veiled, with the result that differences in power and status are largely obscured (Elder-Vass, 2016: 159-61; Forte et al., 2009) - bringing us unusually close to the conditions of Habermas's ideal speech situation and thus to coordination through communication oriented to achieving agreement. And those debates are strongly shaped by a set of norms and values that are themselves published on Wikipedia pages and thus determined by the same process - bringing us unusually close to the model of discourse ethics also advocated by Habermas (Habermas, 1990).

This is not to say that Wikipedia is a perfect case. There is still authority, held by admins, the Arbitration Committee, and by the co-founder Jimmy Wales, though it is exercised relatively 
rarely and mostly in a spirit of consultation (Elder-Vass, 2016: 165-7; Reagle, 2010: 6). There are pages where groups of politically motivated editors gang up on contributors they disagree with rather than debating openly in the spirit of reaching agreement. And there are paid staff in the Wikimedia Foundation, which does not create the content on Wikipedia but does provide the technology and raise the money that funds the site. Still, these are relatively marginal qualifications, suggesting that Wikipedia is largely shaped by lifeworld forces.

If, however, we reject the dominant discursive trope of identifying the economy purely with the market, Wikipedia also belongs firmly in the economy. It produces a product that huge numbers of people find useful, and a product that was formerly produced within the market sector of the economy. Other producers such as Encyclopaedia Britannica once made substantial profits by selling encyclopaedias door to door (Channick, 2014; Dalby, 2009: 28-31; Elder-Vass, 2016: 14851 ) and no-one doubted that producing encyclopaedia articles was an economic activity then. Why should we doubt it now?

This drives another nail into the coffin of the idea that there is a fixed relationship between the lifeworld/systems distinction and the social subsystems of Parsons's model. The very concept of a lifeworld economy disrupts these neatly aligned distinctions, and yet Wikipedia seems like a clear empirical case. Indeed Wikipedia is an encouraging case of decolonisation: a set of economic activities that were governed more by systems mechanisms but are now governed more by lifeworld mechanisms. Colonisation, it seems, is not an inexorable logic but rather situationally specific - and we can see Wikipedia as precisely the sort of resistance to colonisation that Habermas wants to encourage. The rise of Internet technology has opened up possibilities for its reversal, though as we shall see when we turn to discuss open source software the situation is far more complex than this might at first suggest.

\section{Varieties of open source software}

Open source software began life as a vehicle for a strongly lifeworld oriented concept of the digital economy. It is distinguished from most commercial software by the fact that it is supplied with a copy of the source code (hence 'open source'), which is the version of the software that can be understood and edited by human programmers. It is also distinguished by a licensing regime that allows anyone with the requisite skills to edit and improve the software (Elder-Vass, 2014; Stallman, 2010: 3). The concept of open source software does not necessarily require it to be free, but the licensing regimes that it has been linked to make it freely copiable and thus charging for it is usually unsustainable in a world where digital content can be transferred around 
the world at virtually zero cost. Successful open source software products attract communities of programmers who take it upon themselves to improve the software, typically by adding new functions and by fixing problems reported by users. Like the editors of Wikipedia, independent open source coders are largely self-organising in the sense that they choose their own tasks, execute them without supervision, then submit their product to a communal process of further editing and selection (Benkler, 2013; Elder-Vass, 2015b: 220-6). Like Wikipedia editors, these programmers work for nothing, then release the product back to the user community for nothing. Like Wikipedia, open source communities need coordination mechanisms to establish which edited versions of the code should be accepted into the publicly released versions of the software, and like Wikipedia, these tend to be based on strongly communicative and consensual processes. This 'pure' version of the open source process is therefore another example of a closeto-purely-lifeworld economic form. Like Wikipedia, we cannot reasonably dispute that its product is an economic good. Not only does it benefit billions of people around the world (though many of them are unaware of using it), but also equivalent products were previously sold for profit in the commodity economy (and often still are). Like Wikipedia, this means that open source software is a fascinating example of decommodification, and thus of the decolonisation of the economy, and like Wikipedia this has been made possible in part by the technological characteristics of the Internet.

Unlike Wikipedia however, some of the most successful open source communities have been infiltrated or even taken over by commercial businesses. Linux, one of the most successful open source software products, is an operating system that is currently used on $36 \%$ of the servers on the Internet (W3techs.com, 2016b), and thus plays a part in delivering content to the vast majority of web users on a daily basis. ${ }^{9}$ Although it began as a product coded by independent programmers, in recent years an increasing proportion of the coding has been done by employees of commercial software companies as part of the work they do for their employers. Between 2005 and 2012 over $80 \%$ of changes to Linux were made by programmers working for commercial software companies (Corbet et al., 2012: 9). Although the data collection process behind this statistic did not distinguish between work done by an employee for their employer and work done in their own time, it is clear from further contextual evidence that most of this is paid work, done for commercial companies, who are the real donors of this work to the project. ${ }^{10}$

Commercial companies may sometimes contribute to open source projects out of a sense of moral obligation to support communities whose work has benefitted them (Anderson-Gott, Ghinea and Bygstad 2011, 113). However, the predominant motivations are more profit oriented. 
In particular, many of these companies profit from selling complementary products and services (Weber 2004, 195-203). IT services companies who are actively involved in developing an open source product develop deep expertise that enables them to provide support and integration services to companies that wish to use that product. They can offer, for example, to write fixes and new function for a customer which will then become part of the open source product (Anderson-Gott, Ghinea and Bygstad 2011, 109). ${ }^{11}$ Given that large numbers of private companies use Linux for the simple instrumental reason that it is cheaper than commercial alternatives, there is a large market for such services.

Linux has thus become a hybrid of the lifeworld and systems models. It continues to be a free product, with commercial companies and independent coders donating updates to the community, coordinated by a non-profit foundation through democratically structured processes of communicative interaction, and lifeworld mechanisms therefore play a major role in shaping Linux. Yet the commercial software companies have evolved linked practices that deliver commodity sales and profit, and this affects the directions in which Linux is developed as these sales depend on providing features and fixing problems that are important to the enterprise customers of the software companies. The systems pressures arising in the related markets for consulting and support services therefore also play a significant role in shaping Linux. The central role of commercial contributors has by no means eliminated all of the lifeworld features of the model, but it has attenuated them.

\section{Reconstructing the critique}

As the preceding examples have shown, framing lifeworld and systems as distinct sets of causal mechanisms has at least one advantage over Habermas's version of the distinction: it is possible to apply the concepts empirically, and to distinguish between lifeworld and systems aspects of phenomena - lifeworld and systems tendencies, we may say - while recognising that the phenomena themselves may often have both aspects. But where does this leave the critical significance of the distinction? Although his message is more subtle than 'lifeworld good, systems bad', there is no doubt that part of the purpose of Habermas's argument is to provide a foundation for the critical claim that systems mechanisms are becoming dominant in social areas where they are inappropriate. If we reduce his argument to a characterisation of different kinds of causal mechanism, have we lost the element that enabled him to be critical of this move?

In one sense we have. Habermas's version of the lifeworld concept smuggled in some ethical presuppositions (Outhwaite, 1994: 114). He read it as implying (a) that systems mechanisms were 
undesirable, at least in some areas of society, and (b) as providing a standard of which areas of society they were unsuitable for. The strongly functionalist orientation of his perspective suggests that communicative rationality is to be preferred in the public and private spheres because it is more effective at integrating social action in those areas, while systems mechanisms are to be preferred in other areas for the same reason. Yet there is no clear justification of these claims for greater effectiveness in the areas concerned, indeed he seems to have simply conceded to mainstream economics and nascent neoliberalism that the economy is best coordinated by markets.

But if, as I and many others have argued, the concepts of lifeworld and systems fail to refer to an empirically distinguishable area of social activity then Habermas's argument cannot provide an adequate foundation for these critical claims: in particular, it no longer identifies which activities should be kept out of the grip of systemic influences. Furthermore, if we abandon a functionalist framework that implicitly prioritises the 'needs' of society over those of its members, we may no longer use integrational effectiveness as a criterion for preferring lifeworld mechanisms to systems mechanisms. If we are to be critical about the role of systems we will have to offer more explicit justifications for the claim that lifeworld mechanisms are preferable to systems mechanisms in any given area.

With the help of Habermas's own later work on discourse ethics we may be able to sketch out the beginnings of such a justification. Let me begin from his discourse principle: 'Just those action norms are valid to which all possibly affected persons could agree as participants in rational discourses' (Habermas, 1996: 107). It is beyond the scope of this paper to evaluate this principle, but I have offered some arguments in its favour elsewhere (Elder-Vass, 2010a: 49-53). ${ }^{12}$ The principle, at least implicitly, expresses the idea that social decisions about which ways of doing things are preferable ought to be made through communicatively rational discourses. To put it another way, it assumes that lifeworld mechanisms are to be preferred over systemic forces in decision making. While Habermas originally framed the distinction in functionalist terms, we can transform his reasons for preferring lifeworld mechanisms into terms that are more oriented to human needs: lifeworld mechanisms are more likely to lead to outcomes that are acceptable to all because they achieve maximal justice by allowing the views of all to be heard, as opposed to favouring the interests of those with money or power, as systems mechanisms tend to do.

When it is framed in these terms, the presumption that lifeworld mechanisms are more just is not confined to restricted areas of society - it applies, in particular, to the state and the economy 
as well as to the private and public spheres. It does not entail, however, that lifeworld mechanisms are always or necessarily preferable to systems mechanisms; the initial presumption in their favour is only one factor. Like any branch of ethics, critical evaluation is complex because there are always multiple factors to be taken into account. A further factor here is that system mechanisms may sometimes be so much more efficient than inclusive debate that everyone would be better off relying on them then addressing the issue concerned through deliberative dialogue. Both neoclassical economics, with its notion of Pareto equilibria, and Hayek's account of the market as an information processor suggest that this might be true of the market. We need not accept these particular arguments to recognise that arguments like them might challenge an ethical preference for lifeworld mechanisms in specific areas.

How, though, could we identify which areas would benefit from systems mechanisms, from a critical perspective? I suggest that issues like this could be resolved within the framework of discursive democracy, by making the decision about the role that systems mechanisms are allowed to play a topic for discursive debate and agreement. We might then expect systems alternatives to be preferred when they have an advantage, e.g. in efficiency terms, that offsets the discursive advantage of lifeworld mechanisms to a degree that makes them generally acceptable.

The disadvantage of this sort of deliberative approach to critique is that it does not generate simple critical distinctions or neat slogans like 'the colonisation of the lifeworld'. The advantage, however, is that it reverses the default assumptions of contemporary governmental discourse without dogmatically attributing pathologies to systems mechanisms. In place of neoliberalism's privileging of strategic rationality over communicative rationality, deliberative critique appeals to discursive mechanisms to adjudicate on the potential benefits of systems mechanisms.

\section{Conclusion}

Habermas's distinction between lifeworld and systems is highly problematic. His formulations of the difference tend to conflate a range of different distinctions that are often incongruent with each other. These cannot be held together once we seek to apply this model to empirical cases, and so if the central conceptual innovation is to be of any empirical relevance at all, we must split its different constituent distinctions apart from each other and identify one that is to be the core. Neither types of action nor domains of action can plausibly be divided into lifeworld and systems, hence this paper has investigated the possibility of seeing lifeworld and systems as types of causal mechanism. In doing so it not only refines the distinction but also repositions it, moving it 
out of a functionalist framing of social analysis and into a realist frame that is oriented to constructing multi-factor causal explanations.

On this account lifeworld refers to causal mechanisms that arise from the communicative features of interaction, and systems to those mechanisms that arise from the use of steering media such as money and power: mechanisms that influence events through processes that are not oriented to reaching agreement. One consequence of this reframing is that particular empirical phenomena can be related to the distinction. But this does not mean that we can simply pigeonhole each phenomenon neatly into one box or the other. On the contrary, events are always influenced by multiple mechanisms, and so any given event may be produced by a mix of lifeworld and systems mechanisms. We may, loosely speaking, portray some events as more systems-influenced and others as less, but there need not be any events that fit the ideal types of a purely systems event or a purely lifeworld event.

One benefit of this approach is that it allows us to apply the distinction to the real economy in all its diversity. Much of the economy is not coordinated by money and markets, and thus the lifeworld may play a significant role in it - a role that Habermas's usual identification of the economy with systems tends to marginalise. Hence the relation of economic phenomena to lifeworld and systems cannot be taken for granted but must be questioned and analysed in each case. There are economic forms that are dominated by the logic of systems but there are also others that are not. Indeed there may also be other social logics or mechanisms that do not fit in either of Habermas's categories, not least the causal influence of technology on events in the digital economy - a pivotal case of the causal impact of non-human material objects on social events (Elder-Vass, 2017).

I claim that the reformulation investigated here provides us with a way of employing Habermas's distinction that is empirically relevant and ontologically plausible. But where does it leave his critical agenda? I have suggested that it undermines the structure of his critical argument, but this may be an advantage rather than a problem: it forces us to make the ethical argument more clearly and to offer concrete justifications for it, which may ultimately be more persuasive than generalisations based on loose abstractions. Habermas highlights the appealing argument that commercial and administrative power are reaching too far into our lives, but has no coherent way of locating the boundaries beyond which they should not go.

Ultimately, the move proposed here sharpens the critique. By discarding the functionalist framework and the problematic assumptions about distinct spheres with different integrative 
logics, we can concentrate on the central issue that Habermas's distinction brings into focus: the conflict between two classes of mechanism liberated by modernity. On the one hand we have the humanising logic of communicative rationality, realised in democracy, cosmopolitanism, internationalism, and struggles against prejudice and discrimination. On the other the objectifying logic of instrumental rationality, realised in the extension of bureaucratic power and the spread of commodification. While instrumental rationality has its place, we need to discard the assumption that the whole economy is its realm and instead open our eyes to both the existence and the value of lifeworld forms of economy. Digital technology has opened the doors to some new varieties of lifeworld economy and in the process created new opportunities for provisioning that responds to human needs rather than money and power.

\section{Acknowledgements}

I would like to thank Daniel Chernilo, Dean Curran, Nikos Sotirakopoulos, Iris Wigger and this journal's reviewers for their very useful comments on earlier drafts, and Janaki Srinivasan and Ashwin Matthew for discussing the paper at the 2016 SASE conference in Berkeley.

\section{Notes}

\footnotetext{
${ }^{1}$ Although he does not use the term provisioning, as far as I am aware, the core idea here comes from Polanyi, with his claim that there is a substantive economy in which people interact with their environment to supply "the means of material want satisfaction" and that the formal economy of rationalisation in the market studied by economists refers to only a subset of substantive economic activity (Polanyi, 2001: 2434).

${ }^{2}$ A pen name for two collaborating authors, hence I refer to them in the plural.

${ }^{3}$ There are also, of course, substantial reasons to doubt the adequacy of mainstream economics for analysing even the market economy (see, for example Keen, 2011; Lawson, 1997, 2003).

${ }^{4}$ Indeed, his entire social ontology appears to be driven by this critical agenda, and in particular by his desire to find a more optimistic response to the dominant position of capitalism than his Frankfurt School colleagues.

${ }^{5}$ I thank Daniel Chernilo for this point.

${ }^{6}$ A move that is also proposed by Plumb (2014: 54-5).

${ }^{7}$ At first sight it may seem that Habermas and Bhaskar take radically opposed perspectives. Most obviously, Bhaskar is known as a realist and Habermas as a constructionist. Yet Habermas has realist moments (e.g. Habermas, 2003: 2-3, 30-36), and Bhaskar sees his realism as entirely compatible with social constructionism (Bhaskar, 1993). We may even argue that realism and moderate social
} 
constructionism are mutually necessary (Elder-Vass, 2012). Bhaskar also drew on Habermas's ethical thinking, though he reached very different conclusions (Bhaskar, 1986: 210; Elder-Vass, 2010a).

${ }^{8}$ Chernilo, for example, challenges the assumption that these are equivalent forms of media (2002: 442).

${ }^{9}$ The open source web serving software Apache has an even larger 'market' share, currently 52\% (W3techs.com, 2016a).

${ }^{10}$ The second half of this paragraph, and much of the following paragraph, is closely based on material from (Elder-Vass, 2014).

${ }^{11}$ Again, this donation of fixes and features is not necessarily altruistic: the terms of open source software licenses have been carefully designed to prevent commercial developers from retaining exclusive rights over modifications they make to the software (Benkler, 2013: 221).

${ }^{12}$ See Finlayson (2000) for a careful discussion of possible justifications of the discourse principle

\section{References}

Benkler Y (2002) Coase's Penguin, or, Linux and The Nature of the Firm. Yale Law Journal 112(3): 369-446.

Benkler Y (2013) Practical Anarchism. Politics and Society 41(2): 213-251.

Bhaskar R (1975) A realist theory of science. 1st ed. Leeds: Leeds Books.

Bhaskar R (1986) Scientific realism and human emancipation. London: Verso.

Bhaskar R (1993) Afterword. In: Shotter J (ed.), Conversational Realities, London: Sage, pp. 185-7.

Boulding KE (1973) The Economy of Love and Fear. Belmont CA: Wadsworth.

Channick R (2014) Encyclopaedia Britannica sees digital growth, aims to draw new users. chicagotribune.com. Available from: http://www.chicagotribune.com/business/ctbritannica-digital-0911-biz-20140910-story.html (accessed 1 January 2015).

Chernilo D (2002) The theorization of social co-ordinations in differentiated societies: the theory of generalized symbolic media in Parsons, Luhmann and Habermas. British Journal of Sociology 53(3): 431-449.

Corbet J, Kroah-Hartman G and McPherson A (2012) Linux Kernel Development. The Linux Foundation. Available from: http://go.linuxfoundation.org/who-writes-linux-2012.

Dalby A (2009) The World and Wikipedia. Somerset: Siduri Books.

Delanty G (1999) Social Theory in a Changing World: Conceptions of Modernity. Oxford, UK ; Malden, MA: Polity.

Elder-Vass D (2007) Luhmann and emergentism: Competing paradigms for social systems theory. Philosophy of the Social Sciences 37(4): 408-432. 
Elder-Vass D (2010a) Realist critique without ethical naturalism or moral realism. Journal of Critical Realism 9(1): 33-58.

Elder-Vass D (2010b) The Causal Power of Social Structures. Cambridge: Cambridge UP.

Elder-Vass D (2012) The Reality of Social Construction. Cambridge: Cambridge UP.

Elder-Vass D (2014) Commerce, community and digital gifts. In: Garnett RF, Lewis P, and Ealy L (eds), Commerce and Community: Ecologies of Social Cooperation, Abingdon: Routledge, pp. 236252.

Elder-Vass D (2015a) Free gifts and positional gifts: Beyond exchangism. European journal of social theory 18(4): 451-468.

Elder-Vass D (2015b) The moral economy of digital gifts. International Journal of Social Quality 5(1): 35-50.

Elder-Vass D (2016) Profit and Gift in the Digital Economy. Cambridge: Cambridge UP.

Elder-Vass D (2017) Material parts in social structures. Journal of Social Ontology.

Finlayson JG (2000) Modernity and Morality in Habermas's Discourse Ethics. Inquiry 43(3): 319-340.

Finlayson JG (2005) Habermas: a very short introduction. Oxford: Oxford UP.

Forte A, Larco V and Bruckman A (2009) Decentralization in Wikipedia governance. Journal of Management Information Systems 26(1): 49-72.

Fraser N (1989) Unruly Practices: Power, Discourse and Gender in Contemporary Social Theory. Cambridge: Polity.

Garnett RF (2007) Philanthropy, economy, and human betterment. Conversations on Philanthropy IV: $13-35$.

Geldman A (2014) Marketplace Repricing: The Ultimate Guide. Web Retailer Blog. Available from: http://www.webretailer.com/lean-commerce/marketplace-repricing-ultimate-guide/ (accessed 26 May 2016).

Gibson-Graham JK (2006a) A Postcapitalist Politics. Minneapolis: University of Minnesota Press.

Gibson-Graham JK (2006b) The End of Capitalism (As we knew it). Minneapolis: University of Minnesota Press.

Gray KW (2014) The Autopoietic Turn in Habermas' Legal Philosophy. Ancilla luris. Available from: http://www.anci.ch/beitrag/gray_kevin (accessed 25 November 2016).

Gruchy AG (1987) The Reconstruction of Economics. Westport CT: Greenwood Press.

Habermas J (1987) The Theory of Communicative Action, Volume 2: Lifeworld and System. Boston: Beacon Press.

Habermas J (1990) Moral Consciousness and Communicative Action. Cambridge: Polity Press. 
Habermas J (1991) A Reply. In: Honneth A and Joas H (eds), Communicative Action: Essays on Jurgen Habermas's The Theory of Communicative Action, Cambridge: Polity, pp. 215-264.

Habermas J (1996) Between Facts and Norms. Cambridge: Polity.

Habermas J (2003) Truth and Justification. Cambridge: Polity.

Hart K, Laville J-L and Cattani AD (2010) The Human Economy. Cambridge: Polity Press.

Ironmonger D (1996) Counting Outputs, Capital Inputs and Caring Labor: Estimating Gross Household Product. Feminist Economics 2(3): 37-64.

Joas H (1991) The Unhappy Marriage of Hermeneutics and Functionalism. In: Honneth A and Joas H (eds), Communicative Action: Essays on Jurgen Habermas's The Theory of Communicative Action, Cambridge: Polity, pp. 97-118.

Jopson B (2012a) From warehouse to powerhouse. Financial Times, 8th July. Available from: http://www.ft.com/cms/s/0/cc3a0eee-c1de-11e1-8e7c-00144feabdc0.html\#axzz3XsA3TC9A (accessed 20 April 2015).

Jopson B (2012b) The Amazon Economy. Portfolio Penguin.

Keen S (2011) Debunking economics. Revised and expanded. London: Zed Books.

Lawson T (1997) Economics and reality. London: Routledge.

Lawson T (2003) Reorienting economics. London: Routledge.

Mauss M (2002) The Gift. London: Routledge.

McCarthy T (1991) Complexity and Democracy: or the Seducements of Systems Theory. In: Honneth A and Joas $\mathrm{H}$ (eds), Communicative Action: Essays on Jurgen Habermas's The Theory of Communicative Action, Cambridge: Polity, pp. 119-139.

Mouzelis NP (1997) Social and system integration: Lockwood, Habermas, Giddens. Sociology 31(1): 111-119.

Nelson JA (1993) The study of choice or the study of provisioning? Gender and the definition of economics. In: Ferber MA and Nelson JA (eds), Beyond Economic Man, Chicago: University of Chicago Press, pp. 23-36.

Outhwaite W (1994) Habermas: a critical introduction. Cambridge: Polity Press.

Plumb D (2014) In Defense of Norm Circles: A New Normative Foundation for Adult Education. International Journal of Adult Vocational Education and Technology 5(2): 45-59.

Polanyi K (2001) The Economy as Instituted Process. In: Granovetter M and Swedberg R (eds), The Sociology of Economic Life, Boulder, CO: Westview Press, pp. 31-50.

Power M (2004) Social Provisioning as a Starting Point for Feminist Economics. Feminist Economics 10(3): 3-19.

Rasmussen DM (1990) Reading Habermas. Oxford: Basil Blackwell. 
Reagle J (2010) Good Faith Collaboration. Cambridge, MA: MIT Press.

Sayer A (2004) Moral Economy. Available from:

http://www.lancs.ac.uk/fass/sociology/papers/sayer-moral-economy.pdf.

Stallman R (2010) Free Software, Free Society. 2nd ed. Boston MA: GNU Press.

Stone B (2014) The Everything Store: Jeff Bezos and the Age of Amazon. Corgi.

W3techs.com (2016a) Usage Statistics and Market Share of Apache for Websites, May 2016.

Available from: https://w3techs.com/technologies/details/ws-apache/all/all (accessed 25 May 2016).

W3techs.com (2016b) Usage Statistics and Market Share of Linux for Websites, May 2016. W3techs Web Technology Surveys. Available from: https://w3techs.com/technologies/details/oslinux/all/all (accessed 25 May 2016).

\section{Author biography}

Dave Elder-Vass is a Reader in Sociology at Loughborough University, UK. His recent book Profit and Gift in the Digital Economy (2016) develops a theory of appropriative practices in the digital economy and their implications for social theory and politics. He has also published extensively on social ontology and social theory from a critical realist perspective, including The Causal Power of Social Structures (2010) and The Reality of Social Construction (2012). 